\title{
Characterization and milk coagulating properties of Cynanchum otophyllum Schneid. proteases
}

\author{
Jie Luo, ${ }^{* 1}$ Chen Xiao, $\dagger^{1}$ Hao Zhang, ${ }^{*}$ Fazheng Ren, ${ }^{*}$ Xingen Lei, ${ }^{*}$ Zibiao Yang, $\ddagger$ and Zhengquan Yu $\S^{2}$ \\ *Beijing Advanced Innovation Center for Food Nutrition and Human Health, College of Food Science and Nutritional Engineering, and \\ †Key Laboratory of Functional Dairy, Co-constructed by Ministry of Education and Beijing Government, \\ and Beijing Laboratory of Food Quality and Safety, China Agricultural University, Beijing 100083, China \\ ¥Dali Vocational and Technical College of Agriculture, Dali 671000, China \\ $\S B e i j i n g$ Advanced Innovation Center for Food Nutrition and Human Health and State Key Laboratories for Agrobiotechnology, \\ College of Biological Sciences, China Agricultural University, Beijing 100193, China
}

\begin{abstract}
The herbaceous plant Cynanchum otophyllum Schneid. is widely used as a milk coagulant to make a Chinese traditional milk product, milk cake. However, the milk-clotting compounds and their mechanism remain unclear. In this study, crude proteases were extracted from the dried leaves of Cynanchum otophyllum Schneid. using citric acid-phosphate buffer and then partially purified by weak anion exchange chromatography. Two proteases, QA and $\mathrm{QC}$, with molecular weights of 14 and $27 \mathrm{kDa}$, respectively, were shown to exhibit milk-clotting activity. A study of the effects of $\mathrm{pH}$ and temperature on the milk-clotting activity and proteolytic activity of the proteases showed that they exhibited good $\mathrm{pH}$ stability from $\mathrm{pH} 5.5$ to 7.5 and good thermal stability at temperatures from 50 to $70^{\circ} \mathrm{C}$. The $\mathrm{QA}$ and $\mathrm{QC}$ were the cysteine proteases, able to hydrolyze $\beta$-casein and $\kappa$-casein completely, and $\alpha$-casein partially. The cleavage site on $\kappa$-casein determined by Orbitrap (Thermo Fisher Scientific, San Jose, $\mathrm{CA}$ ) analysis showed that $\mathrm{QA}$ and $\mathrm{QC}$ could cleave K-casein at Ser132-Thr133. Overall, the results suggest that the Cynanchum otophyllum Schneid. proteases are a promising milk-clotting enzyme that could be used for manufacturing milk cake and cheese.
\end{abstract}

Key words: Cynanchum otophyllum Schneid., milkclotting activity, proteolytic activity, plant rennet

\section{INTRODUCTION}

Milk cake is a traditional milk product which has been consumed for over $600 \mathrm{yr}$ by people from the minority ethnic region in Yunnan province, China (Xiao

\footnotetext{
Received September 24, 2017.

Accepted December 14, 2017.

${ }^{1}$ Jie Luo and Chen Xiao contributed equally to this work.

${ }^{2}$ Corresponding author: zyu@cau.edu.cn
}

et al., 2007). Milk cake is known as Chinese cheese and is usually made of goat, cow, or buffalo milk. Because of its high nutritional value, special flavors, and unique taste, milk cake has become the favorite food of the local people of Yunnan (Tao et al., 2015). However, milk cake is mostly produced by hand in workshops, leading to low yields and uncertain quality, so its manufacturing processes need to be improved.

As milk cake is a type of ready-to-eat fresh cheese, milk clotting directly affects its yield, texture, and sensory quality. Traditionally, milk cake is made typically by heating milk in combination with acid and rennet gelation. Generally, after heating the raw milk to boiling point, acid whey is added with or without coagulant, then the curd is compressed and molded (Xiao et al., 2007). People in the JianChuan and HeQing counties of Yunnan province have accidentally found that the solution produced by soaking a local plant, Cynanchum otophyllum Schneid., could be used as a coagulant to make milk cake. However, manufacturing this solution has not been standardized regarding the soaking temperature and ratio of water to leaves, so that the milk-clotting activity (MCA) of the solution can differ greatly. Therefore, developing a coagulant to meet the demands of industrial production of milk cake is very important.

Cynanchum otophyllum Schneid., which belongs to the Asclepiadacene family, is a perennial grass vine that grows in the mountains or valley woodlands at elevations of 1,500 to $2,800 \mathrm{~m}$, particularly in Jianchuan county, Yunnan province (Shen et al., 2014). Studies on C. otophyllum have focused mainly on its pharmacological effects, with its active ingredients being identified as steroid esters that have important biological functions such as anti-epileptic effects (Zhao et al., 2013). However, the milk-clotting mechanism of C. otophyllum remains unstudied.

Calf rennet, which consists of over $90 \%$ chymosin, has been widely used in the manufacture of cheese (Kumar 
et al., 2010). The global increase in cheese production coupled with the preferences of religious and vegetarian consumers has prompted a search for an alternative milk-clotting coagulant from a nonanimal source, such as plant rennet. Several proteases extracted from plants such as kiwi, papaya, ginger rhizome, and cardoon (Cynara cardunculus) have been successfully used as milk-clotting coagulants for cheese making in different parts of the world (Jacob et al., 2011). Different plant extract proteases have also been shown to have particular active ingredients, cleavage sites, and conditions for optimal application (Chen et al., 2003; Vairo-Cavalli et al., 2005; Brutti et al., 2012). Cynanchum otophyllum is a promising plant rennet so separating and purifying its proteases and clarifying its milk-clotting mechanism are very important and need to be investigated.

The present study aims to separate and purify the proteases of $C$. otophyllum, then to determine the effects of temperature and $\mathrm{pH}$ on the MCA and proteolytic activity (PA) of the proteases. The products of protease degradation and the cleavage sites of the enzymes on $\kappa-\mathrm{CN}$ will also be investigated. A better understanding of the milk-clotting characteristics of the C. otophyllum proteases could contribute to developing a plant rennet for the industrial production of milk cake.

\section{MATERIALS AND METHODS}

\section{Samples and Reagents}

Samples of C. otophyllum Schneid. (Chinese name Qingyangshen) were collected from Jianchuan county (2,000 $\mathrm{m}$ above sea level) in Dali City, Yunnan province. After natural drying, the C. otophyllum samples were stored in a freezer at $-20^{\circ} \mathrm{C}$ until processing. Skim milk powder was obtained from Nouriz Dairy Co. (Shanghai, China); Q Sepharose Fast Flow from GE Healthcare (Uppsala, Sweden); calf rennet, Naturen Stamix 1150 NB, from Chr. Hansen (Hoersholm, Denmark); bromelain, papain, whole casein, $\alpha-\mathrm{CN}, \beta-\mathrm{CN}, \kappa-\mathrm{CN}$, and BSA from Sigma-Aldrich (St. Louis, MO); Coomassie Brilliant Blue G-250 and R-250 from Bio-Rad Laboratories (Hercules, CA); and 10-kDa ultrafiltration tubes from Millipore (Billerica, MA). All other chemicals were of analytical grade.

\section{Extraction and Partial Purification of Protease}

Extraction. The C. otophyllum proteases were extracted as described by Huang et al. (2011) with some modifications. The $C$. otophyllum leaves were cut into pieces, mixed with $10 \mathrm{mmol} / \mathrm{L}$ of citric acid-phosphate buffer (pH 6.5, containing $1.0 \mathrm{mmol} / \mathrm{L}$ of EDTA and cysteine), then left for $2 \mathrm{~h}$ at $4^{\circ} \mathrm{C}$.
Separation and Partial Purification. After successive filtration through 4 layers of cheesecloth and a $0.22-\mu \mathrm{m}$ membrane, the filtrate was concentrated by ultrafiltration with a $10-\mathrm{kDa}$ molecular weight cut-off membrane. The retentate was then applied to a E-C Polypropylene column $(1.5 \times 12 \mathrm{~cm})$ packed with $\mathrm{Q}$ Sepharose Fast Flow, which had been equilibrated with $10 \mathrm{mmol} / \mathrm{L}$ of citric acid-phosphate buffer ( $\mathrm{pH}$ 6.5). Elution was performed with gradient elute of 0, 0.6, and $1.0 \mathrm{mmol} / \mathrm{L}$ of $\mathrm{NaCl}$ (in binding buffer) to obtain 4 fractions of partially purified enzyme extracts. All fractions were monitored at $280 \mathrm{~nm}$ using a UV detector (UV-2102 PC, Unico Instrument Co. Ltd., Shanghai, China) to detect the proteins. The protein concentration of each fraction was measured following the method of Bradford (1976), whereas the molecular weights of the fractions were determined using SDS-PAGE as described by Laemmli (1970). All the extraction and purification processes were carried out below $10^{\circ} \mathrm{C}$ to protect the enzyme activity.

\section{Milk Clotting Activity Assay}

The MCA of the C. otophyllum proteases was determined using a modified method of He et al. (2011). One milliliter of substrate ( $12 \%$ skim milk in $10 \mathrm{mM} \mathrm{CaCl}$, $\mathrm{pH}$ 6.5) was incubated at $37^{\circ} \mathrm{C}$ for $5 \mathrm{~min}$, then $0.1 \mathrm{~mL}$ of enzyme was added. The time needed for curd formation was recorded and the MCA was expressed in Soxhlet units (SU). One SU of MCA was defined as the amount of enzyme required to clot $1 \mathrm{~mL}$ of substrate within 40 min at $37^{\circ} \mathrm{C}$. The MCA of calf rennet, bromelain, and papain were also determined as a comparison.

\section{Caseinolytic Activity Assay}

The PA of the C. otophyllum proteases was determined using a method modified from Mohanty et al. (2003). The substrate was prepared by dissolving $1 \%$ (wt/vol) of whole casein in $10 \mathrm{mmol} / \mathrm{L}$ of citric acidphosphate buffer ( $\mathrm{pH}$ 6.5). The assay was performed by incubating $1.1 \mathrm{~mL}$ of substrate with $0.1 \mathrm{~mL}$ of partially purified enzyme at $37^{\circ} \mathrm{C}$ for $30 \mathrm{~min}$ and terminated using $1.8 \mathrm{~mL}$ of $5 \%$ (wt/vol) trichloroacetic acid (TCA). The control was prepared by adding the same amount of TCA to the protease, then adding the substrate. After 30 min standing at room temperature, the completely precipitated proteins were removed by centrifuging at $5,000 \times g$ for $20 \mathrm{~min}$ at room temperature. The protein content in the supernatant was then measured at 280 nm (UV-2102 PC, Unico Instrument Co. Ltd.). One unit of PA was defined as the amount of enzyme extract required for an increase of 0.01 in optical density in $1 \mathrm{~min}$ at $280 \mathrm{~nm}$. 


\section{Milk Clotting Characteristics}

Effects of $p H$ and Temperature. The effect of $\mathrm{pH}$ on MCA was studied using $10 \mathrm{mmol} / \mathrm{L}$ of citric acid-phosphate buffer at $\mathrm{pH} 5.5$ to 8.5. The effect of temperature on MCA was determined at temperatures ranging from 40 to $85^{\circ} \mathrm{C}$. The MCA was determined as described earlier.

Kinetics Analysis of the $\kappa$-Casein by the Proteases. The hydrolysis kinetics of $\kappa-\mathrm{CN}$ by the proteases was evaluated as described by Nafi' et al. (2014) with some modifications. Five $\mathrm{mg} / \mathrm{mL}$ of $\kappa$-CN stock solution was dissolved in $10 \mathrm{~m} M$ citric acid-phosphate buffer ( $\mathrm{pH}$ 6.5), then diluted with the buffer to concentrations of $0.1,0.5,1,1.5$, and $2.0 \mathrm{mg} / \mathrm{mL}$. The diluted solutions were first incubated at $37^{\circ} \mathrm{C}$ for 5 min, then the proteases were added at a ratio of 1 to 10 ( $\mathrm{vol} /$ vol). After reacting for $10 \mathrm{~min}$, the same volume of $5 \%$ (wt/vol) TCA was immediately added to terminate the reaction. The kinetic parameters, Michaelis constant $\left(K_{\mathrm{m}}\right)$, catalytic turnover number $\left(k_{\text {cat }}\right)$, and proteolytic coefficient $\left(k_{\text {cat }} / K_{\mathrm{m}}\right)$, were calculated using the Lineweaver-Burk plot (Lineweaver and Burk, 1934).

\section{Proteolytic Properties}

Effects of $\boldsymbol{p H}$ and Temperature. The effect of $\mathrm{pH}$ on PA was determined by incubating the enzyme extracts with $1 \%$ (wt/vol) bovine whole casein substrate at different $\mathrm{pH}$ values (5.5-8.5, using $10 \mathrm{~m} M$ citric acid-phosphate buffer) at $37^{\circ} \mathrm{C}$ for $30 \mathrm{~min}$. The effect of temperature on $\mathrm{PA}$ was determined at temperatures from 40 to $85^{\circ} \mathrm{C}$. The PA was determined as described above.

Determination of Protease Type. The type of protease was determined as described by MazorraManzano et al. (2013) with modification. Different protease inhibitors $(8 \mathrm{mmol} / \mathrm{L}, 0.1 \mathrm{~mL})$, a serine protease (phenylmethylsulfonyl fluoride, PMSF), a cysteine protease [transepoxy-succinylleucyl-amido-(4guanidino)-butane, E-64], a metallo protease (EDTA), and an aspartic protease (pepstatin A), were added to $1 \mathrm{~mL}$ of the proteases. The mixtures were incubated at $37^{\circ} \mathrm{C}$ for $30 \mathrm{~min}$, then PA was evaluated. The percentage inhibition was calculated as follows:

$$
\begin{gathered}
\text { percentage inhibition }=100-[100 \\
-(\text { residual activity/activity without inhibitor })] .
\end{gathered}
$$

\section{Hydrolysis of Casein}

The level of casein hydrolysis was determined as described by Huang et al. (2011). Bovine $\alpha-\mathrm{CN}, \beta-\mathrm{CN}$, and $\kappa-\mathrm{CN}$ (50 mg each) were prepared separately by dissolving them in $10 \mathrm{~mL}$ of $10 \mathrm{mmol} / \mathrm{L}$ of citric acidphosphate buffer ( $\mathrm{pH}$ 6.5). The proteases were added to each substrate at a ratio of 1:10 then hydrolyzed at $65^{\circ} \mathrm{C}$ for 5,15 , and $30 \mathrm{~min}$ and 1,2 , and $4 \mathrm{~h}$. The degree of degradation was analyzed using SDS-PAGE.

\section{Analysis of the Cleavage Site on $k$-Casein by the Proteases}

The cleavage site on $\kappa$-CN used by the proteases was determined as described by Zhang et al. (2015) with some modifications. $\kappa$-Casein was prepared in 10 $\mathrm{mmol} / \mathrm{L}$ of citric acid-phosphate buffer $(\mathrm{pH}$ 6.5) at a concentration of $5 \mathrm{mg} / \mathrm{mL}$. The proteases were mixed with the $\kappa-\mathrm{CN}$ at a ratio of $1: 10$ and then incubated for $1 \mathrm{~h}$ at $60^{\circ} \mathrm{C}$ to completely ensure the milk was clotted. The mixture was mixed with the loading buffer in a $95^{\circ} \mathrm{C}$ water bath for $5 \mathrm{~min}$ and then separated using urea SDS-PAGE. The target product bands were excised from the gel and then digested by trypsin overnight at $37^{\circ} \mathrm{C}$. The digests obtained were lyophilized and then analyzed using an Orbitrap MS (LTQ Orbitrap XL, Thermo Fisher Scientific, San Jose, CA).

\section{Statistical Analyses}

All measurements were performed in triplicate. The data were analyzed by 1-way ANOVA (with Duncan's multiple range method) or the $t$-test using SPSS software (version 22.0, IBM, Armonk, NY). The level for statistical significance was set at $P<0.05$.

\section{RESULTS AND DISCUSSION}

\section{Partial Purification of C. otophyllum Proteases}

The C. otophyllum partially purified extracts derived by ultrafiltration were separated into 4 fractions, named QA, QB, QC, and QD. The SDS-PAGE figure showed that the proteases were mainly concentrated in QA and QC, with molecular weights of about 14 and $27 \mathrm{kDa}$, respectively (Figure 1). An extra band with a high abundance existed in the lanes of ultrafiltration concentrate, QA and QC, whose molecular weight was about $10 \mathrm{kDa}$. The extracted fractions of $\mathrm{QA}$ and $\mathrm{QC}$ exhibited a color between green and brown, whereas the fractions of $\mathrm{QB}$ and $\mathrm{QD}$ were colorless (figure not shown); therefore, we considered the band was most likely the nonenzymatic pigment compounds rather than the proteases. As in industrial applications, the purity of enzyme is usually of minor importance when compared with the cost, and it is thereby essential to 


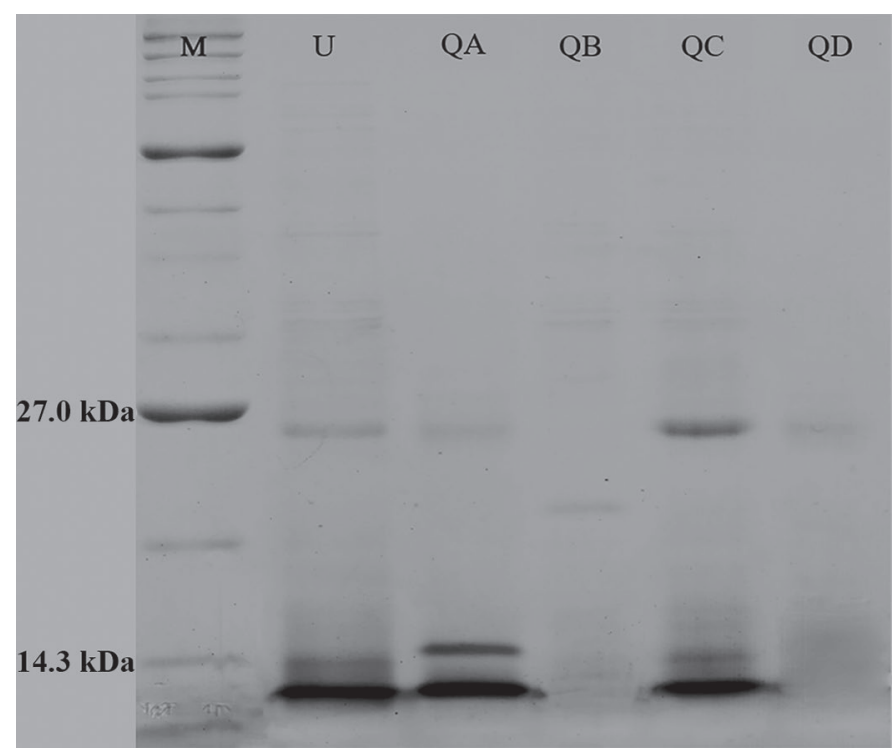

Figure 1. The SDS-PAGE electrophoresis of Cynanchum otophyllum Schneid. proteases. Lane M: protein molecular weight marker; lane $\mathrm{U}$ : ultrafiltration concentrate; other lanes: protein components QA, $\mathrm{QB}, \mathrm{QC}$, and $\mathrm{QD}$, respectively.

characterize the crude protease extract due to its potential use in food technology (Llorente et al., 2014). Therefore, we considered the protease purified in our study could be representative and the evaluation of their biochemical characterization was essential and feasible.

The MCA is the most important property of a milkclotting enzyme. Figure 2 shows that, only the QA and QC fractions enabled the milk to clot, which agreed with the electrophoresis results. The MCA values of QA and QC were 332.6 and $267.4 \mathrm{SU} / \mathrm{mg}$, respectively. Because of the great variety of methods and different units used under different conditions found in the literature, it is difficult to compare the MCA of different proteases. Therefore, we also determined the MCA of calf rennet, bromelain, and papain as a comparison. Figure 2 shows that although the MCA values of QA and QC were lower than that of calf rennet $(16,000$ $\mathrm{SU} / \mathrm{mg}$ ), they were significantly higher than those of bromelain $(222.2 \mathrm{SU} / \mathrm{mg})$ and papain $(100.2 \mathrm{SU} / \mathrm{mg})$. These results have shown that the QA and QC proteases extracted from C. otophyllum have the potential to be milk-clotting enzymes.

In addition to MCA, PA plays a critical role in evaluating the suitability of a milk-clotting enzyme. Proteolysis strongly affects the degradation patterns of caseins, which could further affect the yield and sensory properties of the cheese. Therefore an enzyme with a high MCA and low PA is preferred (Shah et al., 2014). Table 1 shows that the ratios of MCA/PA for $\mathrm{QA}$ and
Table 1. Milk-clotting activity (MCA) and proteolytic activity (PA) of Cynanchum otophyllum Schneid. proteases ${ }^{1}$

\begin{tabular}{lccc}
\hline Protease & MCA $(\mathrm{SU} / \mathrm{mg})$ & PA $(\mathrm{U} / \mathrm{mg})$ & MCA/PA \\
\hline $\mathrm{QA}^{2}$ & $332.6 \pm 1.9^{\mathrm{b}}$ & $8.91 \pm 0.14^{\mathrm{b}}$ & 37.33 \\
$\mathrm{QC}$ & $267.4 \pm 2.7^{\mathrm{a}}$ & $7.40 \pm 0.21^{\mathrm{a}}$ & 36.14 \\
\hline
\end{tabular}

a,b Means in a column with different superscripts are significantly different $(P<0.05)$.

${ }^{1}$ Results are mean $\pm \mathrm{SD}(\mathrm{n}=3)$. SU $=$ Soxhlet unit.

${ }^{2}$ Cynanchum otophyllum Schneid. proteases QA and QC.

QC were 37.33 and 36.14 , respectively, significantly higher values than those of purified enzymes from Onopordum acanthium (9.58), Bromelia hieronymi (4.18), and Philibertia gilliesii (4.82; Brutti et al., 2012).

\section{Milk Clotting Characteristics}

Milk clotting characteristics can be affected by many factors, the foremost being $\mathrm{pH}$ and temperature. Figure $3 \mathrm{~A}$ shows that the MCA of the $C$. otophyllum proteases, $\mathrm{QA}$ and $\mathrm{QC}$, exhibited a similar trend as the $\mathrm{pH}$ varied from 5.5 to 8.5, with the optimum $\mathrm{pH}$ between 5.5 and 7.5. A relative MCA of $30 \%$ was recorded when the $\mathrm{pH}$ was raised to 8.5. This loss of activity under alkaline conditions may be caused by interference from casein aggregation or irreversible changes in the conformation of the casein (Hashem, 2000; Horne and Banks, 2004). The temperature also has a significant influence on $C$. otophyllum proteases. As the temperature increased from 40 to $85^{\circ} \mathrm{C}$, the $\mathrm{MCA}$ of the $\mathrm{QA}$ and $\mathrm{QC}$ proteases

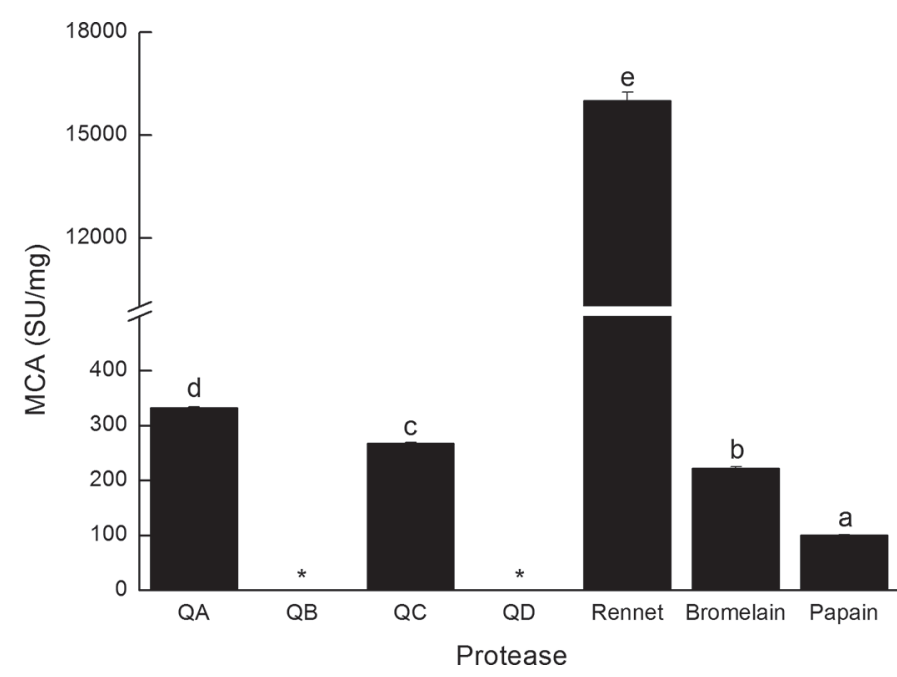

Figure 2. Milk-clotting activity (MCA) of Cynanchum otophyllum Schneid. proteases, QA, QB, QC, QD, and other proteases. Different letters indicate a significant difference between different groups $(P<$ 0.05). SU $=$ Soxhlet unit. ${ }^{*}$ The curd was not formed within $4 \mathrm{~h}$. Error bars represent the SD of triplicate experiments. 
first increased significantly, then decreased sharply, and finally fell to zero (Figure 3B). However, the optimum temperatures for QA and QC were different $\left(65-80^{\circ} \mathrm{C}\right.$ vs. $50-65^{\circ} \mathrm{C}$, respectively). The MCA of QA peaked at $70^{\circ} \mathrm{C}$ at a value of $100 \%$, whereas the activity of QC decreased significantly, with only $21 \%$ remaining at $70^{\circ} \mathrm{C}$ (Figure 3B). This indicated that QA exhibited a better ability to resist heat than QC. Heating may have denatured the whey proteins to form a complex of $\kappa-\mathrm{CN}$ with whey protein, which decreased the effective $\kappa-\mathrm{CN}$ concentration in the substrate and thus increased the curding time (Horne and Banks, 2004). The optimum temperature observed in the $C$. otophyllum proteases was similar to that of the milk-clotting enzyme from ginger $\left(65^{\circ} \mathrm{C}\right.$; Huang et al., 2011) and from melon $\left(70^{\circ} \mathrm{C}\right.$; Mazorra-Manzano et al., 2013), but was significantly higher than that for calf rennet $\left(40-42^{\circ} \mathrm{C}\right.$; Horne and Banks, 2004), probably due to differences in enzyme structure. As the milk clotting for traditional milk cake is usually performed at a temperature of about 65 to $80^{\circ} \mathrm{C}$ with a pH of about 5.5 to 6.0 , the C. otophyllum proteases are thus suitable for producing milk cake.

\section{Kinetic Parameters of $\mathrm{K}-\mathrm{CN}$ by the Proteases}

The higher proteolytic efficiency of chymosin on $\kappa-\mathrm{CN}$, the faster generation of hydrophobic N-terminal moiety of $\kappa-\mathrm{CN}$, the faster the aggregation rate of casein micelles (Shammet et al., 1992). Therefore, evaluation of kinetic parameters of the C. otophyllum proteases on $\kappa$-CN could provide a better understanding of their milk clotting behaviors. The plot of $1 / \mathrm{v}$ versus $1 /[\mathrm{S}]$ for the hydrolysis of $\kappa-\mathrm{CN}$ by the C. otophyllum proteases is shown in Figure 4, with the kinetic parameters calculated from the plots shown in Table 2. $K_{\mathrm{m}}$ is the concentration of substrate required to produce $50 \%$ of the maximum velocity value. A lower $K_{\mathrm{m}}$ indicates a high enzyme affinity to the substrate when the substrate concentration is low, whereas a higher $K_{\mathrm{m}}$ indicates a high enzyme affinity to the substrate only when the substrate concentration is higher (He et al., 2011). The $K_{\text {cat }}$ is the catalytic center activity, and the ratio $k_{\text {cat }} / K_{\mathrm{m}}$ is the proteolytic coefficient, with a high $k_{\text {cat }} / K_{\mathrm{m}}$ indicating a high enzyme proteolytic efficiency on $\kappa$-CN (Vreeman et al., 1986). The $K_{\mathrm{m}}$ of QC (1.708 $\mathrm{mg} / \mathrm{mL})$ was more than 4 times that of QA $(0.397 \mathrm{mg} /$ $\mathrm{mL})$, whereas the $k_{\text {cat }} / K_{\mathrm{m}}$ of $\mathrm{QC}$ was one-fifth that of QA (251.01 vs. $48.95 \mathrm{~mL} / \mathrm{mg} \cdot \mathrm{min})$, indicating a significantly higher enzyme affinity and proteolytic efficiency for QA than QC. The $K_{\mathrm{m}}$ values of the C. otophyllum proteases QA at $37^{\circ} \mathrm{C}$ were consistent with those of ginger proteases at $40^{\circ} \mathrm{C}(0.237-0.359 \mathrm{mg} / \mathrm{mL}$; Huang et al., 2011).

\section{Proteolytic Properties}

The effect of $\mathrm{pH}$ and temperature on the PA of the C. otophyllum proteases were investigated to reveal their proteolytic properties. Figure 5A shows that the proteases QA and $\mathrm{QC}$ both increased at first then significantly decreased as the $\mathrm{pH}$ increased. The PA of protease QA reached an optimum value at $\mathrm{pH} 7$, with over $40 \%$ of residual activity retained over the whole $\mathrm{pH}$ range. The optimum $\mathrm{pH}$ value for $\mathrm{QC}$ was slightly lower ( $\mathrm{pH}$ 6.5), and exhibited a significantly higher residual activity of over $80 \%$ over the whole $\mathrm{pH}$ range (Figure 5A). A variation of $\mathrm{pH}$ in the system can affect the dissociation of the dissociable groups in the activity center and thus affect the PA (Shah et al., 2014). As milk has a natural $\mathrm{pH}$ of 6.5 to 6.7 and

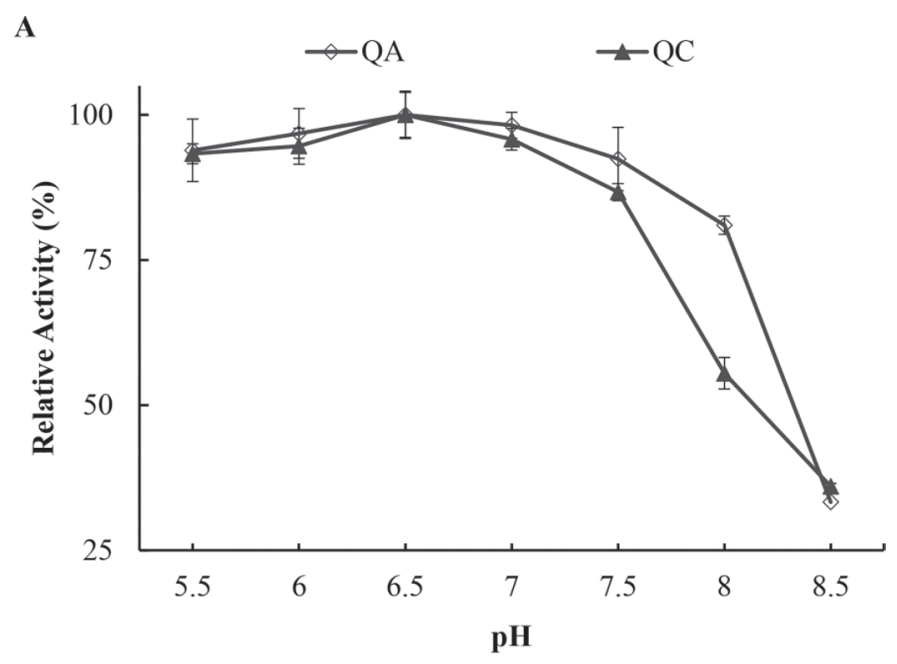

B

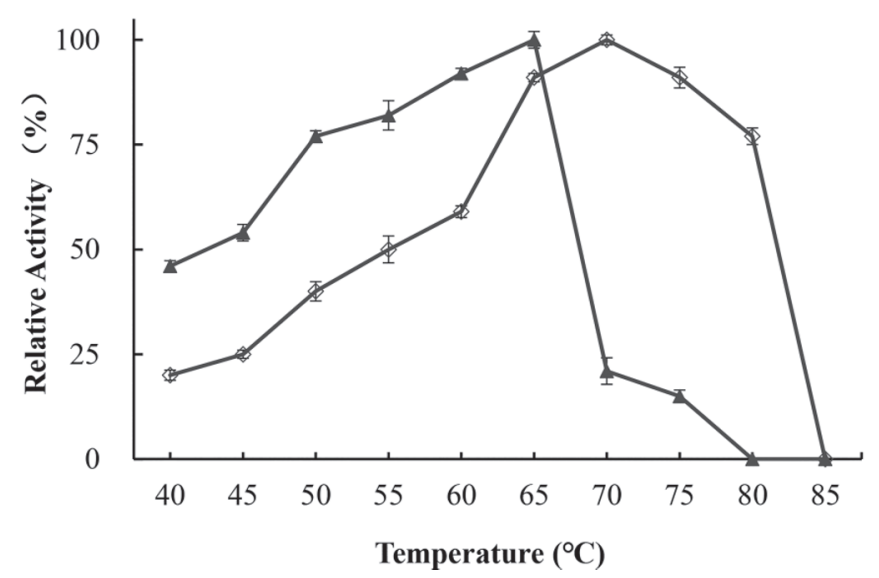

Figure 3. Effect of $\mathrm{pH}$ and temperature on milk-clotting activity of Cynanchum otophyllum Schneid. proteases QA and QC: (A) pH, (B) temperature. Error bars represent the standard deviation of triplicate experiments. 
Table 2. Kinetic parameters of Cynanchum otophyllum Schneid. proteases QA and $\mathrm{QC}^{1}$

\begin{tabular}{lrl}
\hline Protease & \multicolumn{1}{c}{ QA } & QC \\
\hline$K_{\mathrm{m}}(\mathrm{mg} / \mathrm{mL})$ & $0.397 \pm 0.002^{\mathrm{a}}$ & $1.708 \pm 0.014^{\mathrm{b}}$ \\
$k_{\text {cat }}(\mathrm{min})$ & $99.65 \pm 2.32^{\mathrm{b}}$ & $83.61 \pm 1.46^{\mathrm{a}}$ \\
$k_{\text {cat }} / K_{\mathrm{m}}[\mathrm{mL} /(\mathrm{mg} \cdot \mathrm{min})]$ & $251.01 \pm 6.11^{\mathrm{b}}$ & $48.95 \pm 1.93^{\mathrm{a}}$ \\
\hline
\end{tabular}

$\overline{\mathrm{a}, \mathrm{b}}$ Means in a column with different superscripts are significantly different $(P<0.05)$.

${ }^{1}$ Results are mean $\pm \mathrm{SD}(\mathrm{n}=3)$. Michaelis constant $\left(K_{\mathrm{m}}\right)$, catalytic turnover number $\left(k_{\text {cat }}\right)$, and proteolytic coefficient $\left(k_{\text {cat }} / K_{\mathrm{m}}\right)$.

the coagulation of milk cake is usually performed at a $\mathrm{pH}$ of 5.5 to 6.0 , the fact that $C$. otophyllum proteases can maintain PA under neutral and alkaline conditions make them suitable for producing milk cake. The $C$. otophyllum proteases, QA and QC, exhibited similar proteolytic patterns for the temperature dependence of PA (Figure 5B). The QA and QC exhibited a broad optimum temperature range between 40 and $70^{\circ} \mathrm{C}$ for
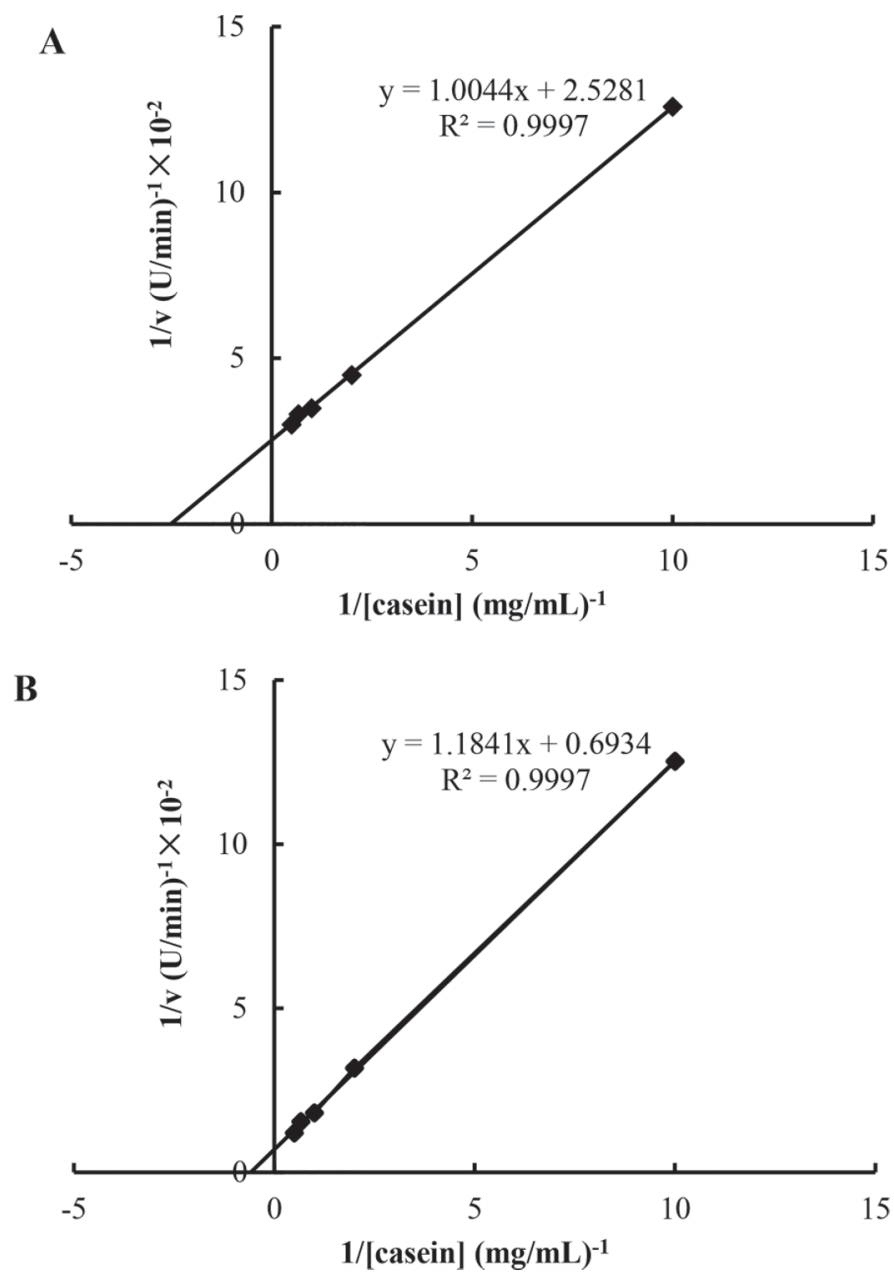

Figure 4. Lineweaver-Burk plots for the hydrolysis of $\kappa$-CN by Cynanchum otophyllum Schneid. proteases QA (A) and QC (B). the hydrolysis of whole casein (Figure 5). The QA and QC also still maintained about $60 \%$ residual activity when the temperature was increased to $80^{\circ} \mathrm{C}$, indicating that $C$. otophyllum proteases were highly resistant to temperature. The $\mathrm{pH}$ and temperature profiles were similar to those of the milk clotting enzymes from $C$. trigonus Roxburghi and S. dubium (Asif-Ullah et al., 2006; Ahmed et al., 2009).

Four different protease inhibitors were used to determine the type of the C. otophyllum proteases. The QA and QC proteases exhibited similar proteolytic patterns with different protease inhibitors (Figure 5C). The effect of metallo protease EDTA and aspartic protease pepstatin A did not affect the PA of the proteases, whereas cysteine protease E-64 dramatically inhibited their activity $(P<0.05)$. This indicated that the $C$. otophyllum proteases were most likely to be a cysteine protease. Proteases purified from ginger, B. hieronymi fruits, and $D$. sinensis have also been shown to be a cysteine protease (Bruno et al., 2010; Nafi' et al., 2014; Zhang et al., 2015). Cysteine proteases, such as papain, bromelain, ficin, and calotropins, have been widely used in dairy processing (Sharma et al., 2012). The activity of QA and QC was also inhibited by serine protease PMSF, by showing about $10 \%$ reduction in the activity (Figure 5). The activity of cysteine proteases extracted from ginger, garlic, and capsules of caper (Capparis spinosa) have all been found to be partially inhibited by PMSF (Parisi et al., 2002; Demir et al., 2008; Nafi' et al., 2013). The reduction of protease activity was most probably caused by PMSF bound to serine with alanine, phenylalanine, or tryptophan residues on the nonactive side of the $C$. otophyllum proteases, thereby reducing the affinity of the substrate with the enzyme and therefore the enzyme activity (Nafi' et al., 2014).

\section{Analysis of Casein Hydrolysate}

Figure 6 compares the specificity of the C. otophyllum proteases on the hydrolysis of isolated $\alpha-\mathrm{CN}, \beta-\mathrm{CN}$, and $\kappa-\mathrm{CN}$ as a function of time at $60^{\circ} \mathrm{C}$. The results showed that $C$. otophyllum proteases could degrade all 3 caseins, with obvious degradation observed after 30 min. $\beta$-Casein and $\kappa$-CN were completely hydrolyzed after $4 \mathrm{~h}$ of incubation, whereas $\alpha-\mathrm{CN}$ was only partially hydrolyzed. In addition, the peptides in all caseins degraded and generated diffuse bands showing those of low molecular weight at the bottom of the gel as the reaction time increased. The number of breakdown products for $\alpha-\mathrm{CN}, \beta-\mathrm{CN}$, and $\kappa-\mathrm{CN}$, was 2,3 , and 1 , respectively. The $\mathrm{QC}$ also exhibited a higher rate of hydrolysis than QA for $\beta-\mathrm{CN}$ and $\kappa-\mathrm{CN}$ but was less for $\alpha-\mathrm{CN}$. Most of the $\kappa-\mathrm{CN}$ was hydrolyzed by QC after 30 min of incubation, but hydrolysis by QA 
required almost $4 \mathrm{~h}$. Previous studies have shown that the cysteine protease actinidin, and the protease from Dregea sinensis Hemsl. could also completely degrade

A

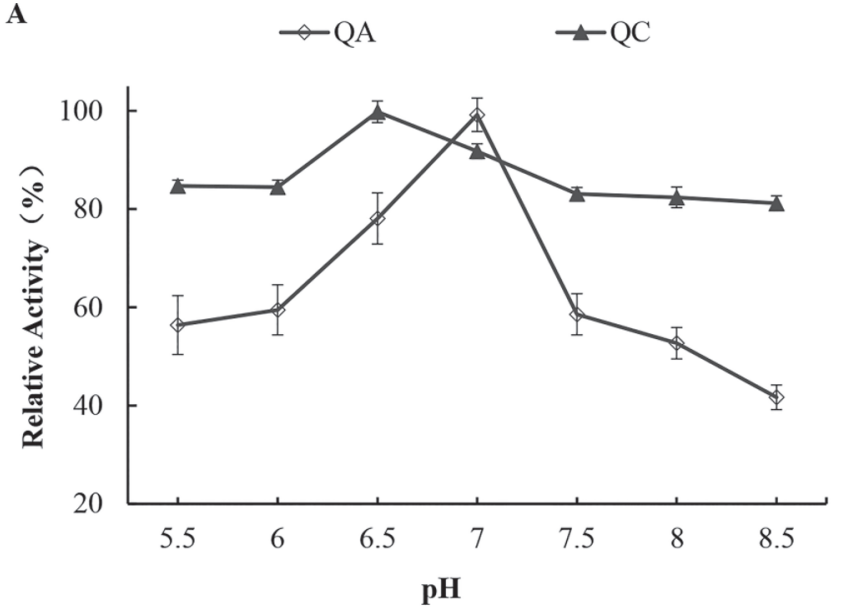

B

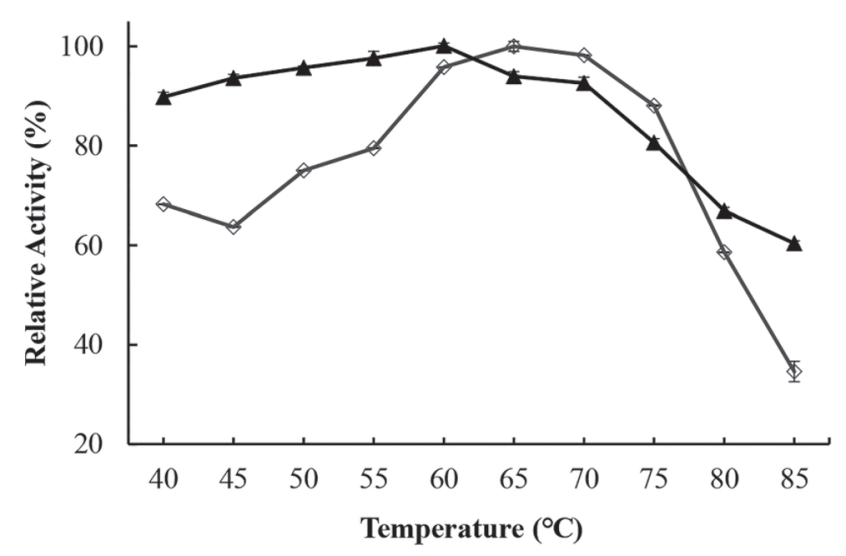

C

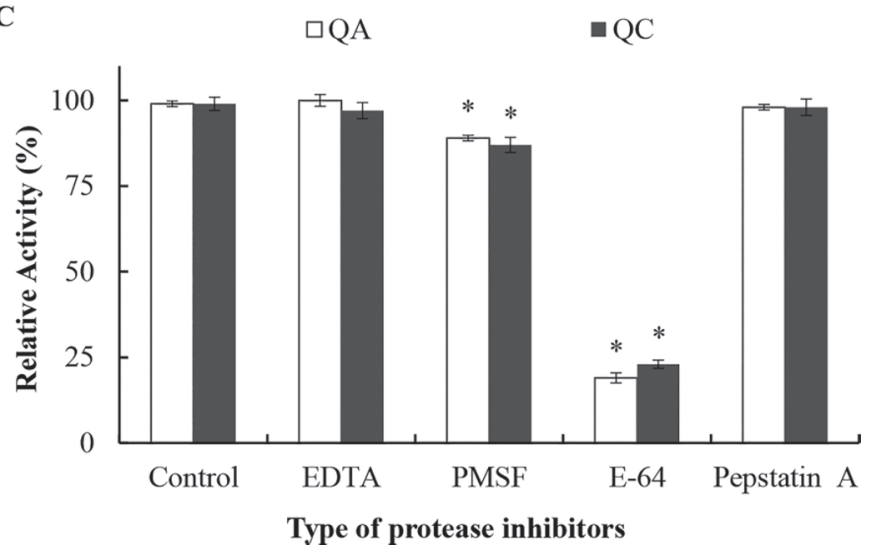

Figure 5. Effect of $\mathrm{pH}$, temperature, and protease inhibitors on the proteolytic activity of Cynanchum otophyllum Schneid. proteases QA and QC: (A) pH, (B) temperature, and (C) protease inhibitors. PMSF $=$ phenylmethylsulfonyl fluoride; E-64 = transepoxy-succinylleucylamido-(4-guanidino)-butane. ${ }^{*}$ Significant difference from the contro $(P<0.05)$. Error bars represent the standard deviation of triplicate experiments.
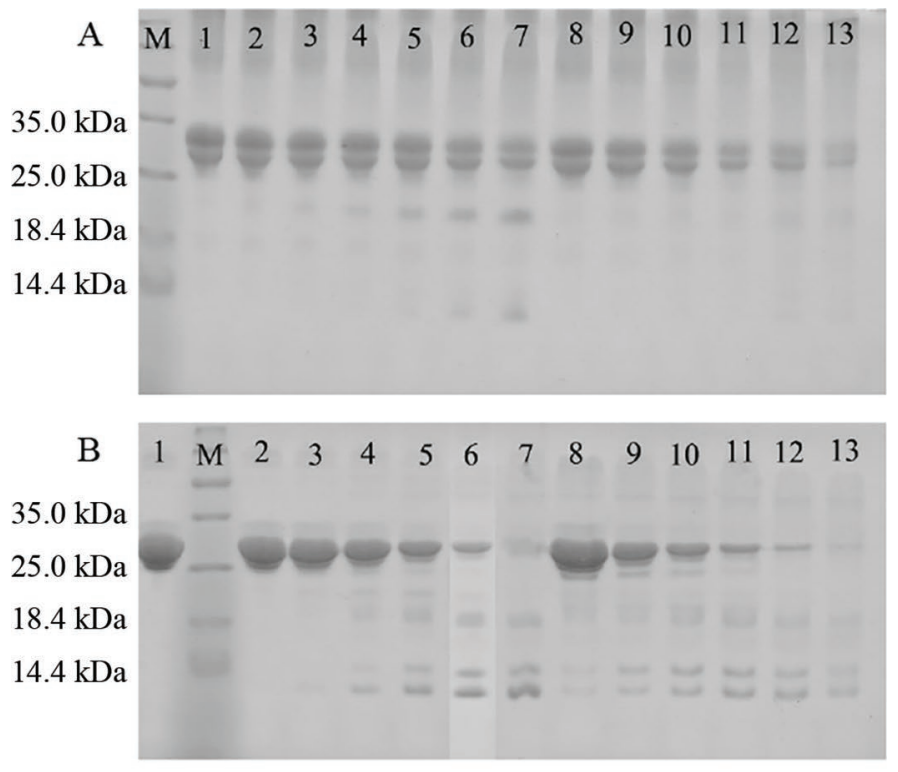

C

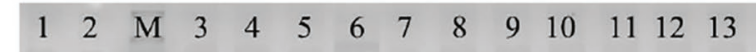

$35.0 \mathrm{kDa}$

$25.0 \mathrm{kDa}$

$18.4 \mathrm{kDa}$

$14.4 \mathrm{kDa}$

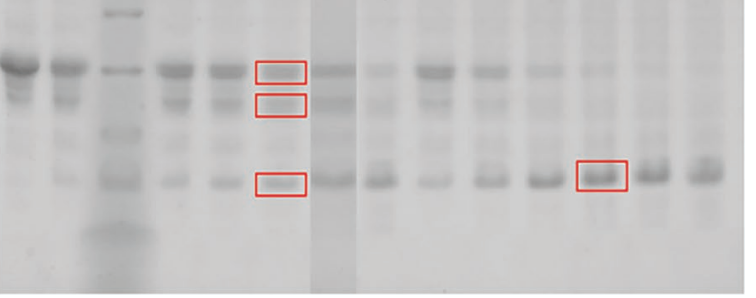

Figure 6. The electrophoresis of hydrolysis whole casein (A), $\alpha-C N$ (B), $\beta-\mathrm{CN}(\mathrm{C})$, and $\kappa-\mathrm{CN}$ (D) by Cynanchum otophyllum Schneid. proteases QA and $\mathrm{QC}$ as a function of time. Lane M: protein molecular weight marker; lane 1: $\alpha-\mathrm{CN}(\mathrm{A}), \beta-\mathrm{CN}(\mathrm{B})$, and $\kappa-\mathrm{CN}(\mathrm{C})$; lanes 2 to 7: casein hydrolyzed by QA at $5 \mathrm{~min}, 15 \mathrm{~min}, 30 \mathrm{~min}, 1 \mathrm{~h}, 2 \mathrm{~h}$, and $4 \mathrm{~h}$, respectively; lanes 8 to 13: casein hydrolyzed by QC at $5 \mathrm{~min}, 15 \mathrm{~min}$, $30 \mathrm{~min}, 1 \mathrm{~h}, 2 \mathrm{~h}$, and $4 \mathrm{~h}$, respectively. Frames indicate that the bands were excised from the gel to determine the cleavage site on $\kappa$-CN by the proteases. Color version available online.

$\beta-\mathrm{CN}$ and $\kappa-\mathrm{CN}$ and partially degrade $\alpha-\mathrm{CN}$ (Lo Piero et al., 2011; Zhang et al., 2015).

\section{The Cleavage Site on $\mathrm{k}$-Casein by the Proteases}

After $1 \mathrm{~h}$ of incubation, the $\mathrm{\kappa}$-CN hydrolysate was excised from the gel to determine the cleavage site on $\kappa$-CN by the proteases, as indicated in the frames of Figure 6C. The peptide sequences obtained of the in-gel digests of peptide segments from $\kappa$-CN are shown in Table 3. Four peptides from the hydrolysate of QA were matched to $\mathrm{k}$-CN with a molecular weight searching (MOWSE) score of 729.38 and 3 peptides from the hydrolysate of QC with a MOWSE score of 988.79. The high MOWSE scores for the C. otophyllum proteases QA and QC indicated an effective identification for the 
Table 3. Identification of peptide sequences of in-gel digests of peptide segments from $\kappa$-CN by Cynanchum otophyllum Schneid. proteases QA and QC using Orbitrap MS ${ }^{1}$

\begin{tabular}{|c|c|c|c|c|c|}
\hline \multirow[b]{2}{*}{ Protease } & \multirow[b]{2}{*}{ Score } & \multirow[b]{2}{*}{ Peptide sequence } & \multicolumn{2}{|c|}{ Molecular weight (Da) } & \multirow[b]{2}{*}{ Peptide origin } \\
\hline & & & $\begin{array}{c}\text { Observed } \\
{\left[(\mathrm{M}+\mathrm{H})^{+}\right]^{2}}\end{array}$ & Calculated & \\
\hline \multirow[t]{4}{*}{$\overline{\mathrm{QA}}$} & \multirow[t]{4}{*}{729.38} & SPAQILQWQVLSNTVPAK & $1,980.08$ & $1,979.08$ & $\kappa-\mathrm{CN}(69-86)$ \\
\hline & & SCQAQPTTMAR & $1,192.56$ & $1,192.53$ & «-CN (87-97) \\
\hline & & HPHPHLSFMAIPPK & $1,608.85$ & $1,607.84$ & $\kappa-\mathrm{CN}(98-111)$ \\
\hline & & KNQDKTEIPTINTIASGEPTS & $2,244.14$ & $2,244.44$ & $\kappa-\mathrm{CN}(112-132)$ \\
\hline $\mathrm{QC}$ & 988.79 & NQDKTEIPTINTIASGEPTS & $2,116.04$ & $2,115.03$ & $\kappa-\mathrm{CN}(113-132)$ \\
\hline
\end{tabular}

${ }^{1}$ gi | 162811 к-CN precursor (Bos taurus); mass: 21,255.89 Da. Orbitrap, Thermo Fisher Scientific (San Jose, CA).

${ }^{2}(\mathrm{M}+\mathrm{H})^{+}$indicates the mass and the charge of the molecular ions.

N-terminal moiety of $\kappa$-CN. The omission of some peptide sequences from the results may have been caused by the further hydrolysis of $\kappa$-CN into small peptides, which could not be detected by the Orbitrap analysis. Moreover, it is well known that trypsin is preferentially cleaved at Arg and Lys in position P1 (Keil, 2012). Therefore, by eliminating the peptides obtained from trypsin and the overlapped peptides, we can conclude that the primary cleavage site of $C$. otophyllum proteases on $\kappa$-CN was Ser132-Thr133. $\kappa$-Casein was hydrolyzed into 2 peptides, $\kappa$-CN (f1-132) with a molecular weight of 15,139.72 Da and $\kappa-C N$ (f133-169) with a molecular weight of $3,840.89$ Da. This result agreed with the molecular weight observed from the electrophoresis results $(\sim 15 \mathrm{kDa}$, Figure 6$)$. The cleavage sites of the C. otophyllum proteases in $\kappa$-CN differed from those of calf rennet, which cleaved at Phe105-Met106 and others reported for plant proteases: Ala90-Glu91, His102-Leu103, and Thr121-Ile122 for ginger protease (Huang et al., 2011); Phe105-Met106, Arg97-His98, Lys111-Lys112, or Lys112-Asn113 for lettuce protease (Lo Piero et al., 2002); and Phe105-Met106 and Lys116-Thr117 for proteases purified from sunflower and albizia seeds (Egito et al., 2007).

\section{CONCLUSIONS}

The partial purification and milk-clotting properties of $C$. otophyllum proteases were investigated in this study. The results indicated that the $C$. otophyllum proteases, QA and QC, exhibiting MCA in a pattern distinct from that of rennet, were cysteine proteases with molecular weights of 14 and $27 \mathrm{kDa}$, respectively. The proteases QA and QC could hydrolyze $\alpha-\mathrm{CN}, \beta-\mathrm{CN}$, and $\kappa-\mathrm{CN}$, with the cleavage site on $\kappa-\mathrm{CN}$ at Ser132Thr133. More importantly, the C. otophyllum proteases exhibited high MCA and PA values over a broad of $\mathrm{pH}$ values $(5.5-7.5)$ and temperatures $\left(50-70^{\circ} \mathrm{C}\right)$, thus proving their applicability to milk cake manufacture and potential use as a bovine rennet substitute. The $C$. otophyllum proteases, QA and QC, were slightly different in their affinity and rate of proteolysis of $\kappa-\mathrm{CN}$ as well as in their optimum applied $\mathrm{pH}$ and temperature. Evaluating how the $C$. otophyllum proteases could be used in milk cake and cheese processing is worth further study.

\section{ACKNOWLEDGMENTS}

Finance support was provided by Yunnan Provincial Science and Technology Department (2014ZA001; Kunming, Yunnan) and China Postdoctoral Science Foundation funded project (2016M591293; Beijing). We thank Philip Creed, from Liwen Bianji, Edanz Group China (www.liwenbianji.cn/ac), for editing the English text of a draft of this manuscript. The authors declare no conflicts of interest, financial or otherwise.

\section{REFERENCES}

Ahmed, I. A. M., I. Morishima, E. E. Babiker, and N. Mori. 2009. Dubiumin, a chymotrypsin-like serine protease from the seeds of Solanum dubium Fresen. Phytochemistry 70:483-491.

Asif-Ullah, M., K.-S. Kim, and Y. G. Yu. 2006. Purification and characterization of a serine protease from Cucumis trigonus Roxburghi. Phytochemistry 67:870-875.

Bradford, M. M. 1976. A rapid and sensitive method for the quantitation of microgram quantities of protein utilizing the principle of protein-dye binding. Anal. Biochem. 72:248-254.

Bruno, M. A., C. M. Lazza, M. E. Errasti, L. M. I. Lopez, N. O. Caffini, and M. F. Pardo. 2010. Milk clotting and proteolytic activity of an enzyme preparation from Bromelia hieronymi fruits. Lebensm. Wiss. Technol. 43:695-701.

Brutti, C. B., M. F. Pardo, N. O. Caffini, and C. L. Natalucci. 2012 Onopordum acanthium L. (Asteraceae) flowers as coagulating agent for cheesemaking. Lebensm. Wiss. Technol. 45:172-179.

Chen, S., J. Zhao, and S. Agboola. 2003. Isolation and partial characterization of rennet-like proteases from Australian cardoon $(C y-$ nara cardunculus L.). J. Agric. Food Chem. 51:3127-3134.

Demir, Y., A. A. Gungor, E. D. Duran, and N. Demir. 2008. Cysteine protease (capparin) from capsules of caper (Capparis spinosa). Food Technol. Biotechnol. 46:286-291.

Egito, A. S., J. M. Girardet, L. E. Laguna, C. Poirson, D. Mollé, L. Miclo, G. Humbert, and J. L. Gaillard. 2007. Milk-clotting activity 
of enzyme extracts from sunflower and albizia seeds and specific hydrolysis of bovine א-casein. Int. Dairy J. 17:816-825.

Hashem, A. M. 2000. Purification and properties of a milk-clotting enzyme produced by Penicillium oxalicum. Bioresour. Technol. $75: 219-222$.

He, X., F. Ren, H. Guo, W. Zhang, X. Song, and B. Gan. 2011. Purification and properties of a milk-clotting enzyme produced by Bacillus amyloliquefaciens D4. Korean J. Chem. Eng. 28:203-208.

Horne, D., and J. Banks. 2004. Rennet-induced coagulation of milk Pages 47-70 in Cheese: Chemistry, Physics and Microbiology. Vol. 1. 3th ed. Academic Press, London, UK.

Huang, X. W., L. J. Chen, Y. B. Luo, H. Y. Guo, and F. Z. Ren. 2011. Purification, characterization, and milk coagulating properties of ginger proteases. J. Dairy Sci. 94:2259-2269.

Jacob, M., D. Jaros, and H. Rohm. 2011. Recent advances in milk clotting enzymes. Int. J. Dairy Technol. 64:14-33.

Keil, B. 2012. Specificity of Proteolysis. Springer Science \& Business Media, New York, NY.

Kumar, A., S. Grover, J. Sharma, and V. Batish. 2010. Chymosin and other milk coagulants: Sources and biotechnological interventions. Crit. Rev. Biotechnol. 30:243-258.

Laemmli, U. K. 1970. Cleavage of structural proteins during the assembly of the head of bacteriophage T4. Nature 227:680-685.

Lineweaver, H., and D. Burk. 1934. The determination of enzyme dissociation constants. J. Am. Chem. Soc. 56:658-666.

Llorente, B. E., W. David Obregon, F. X. Aviles, N. O. Caffini, and S. Vairo-Cavalli. 2014. Use of artichoke (Cynara scolymus) flower extract as a substitute for bovine rennet in the manufacture of Gouda-type cheese: Characterization of aspartic proteases. Food Chem. 159:55-63.

Lo Piero, A. R., I. Puglisi, and G. Petrone. 2002. Characterization of "lettucine," a serine-like protease from Lactuca sativa leaves, as a novel enzyme for milk clotting. J. Agric. Food Chem. 50:2439 2443.

Lo Piero, A. R., I. Puglisi, and G. Petrone. 2011. Characterization of the purified actinidin as a plant coagulant of bovine milk. Eur. Food Res. Technol. 233:517-524.

Mazorra-Manzano, M. A., T. C. Perea-Gutierrez, M. E. Lugo-Sanchez, J. C. Ramirez-Suarez, M. J. Torres-Llanez, A. F. Gonzalez-Cordova, and B. Vallejo-Cordoba. 2013. Comparison of the milk-clotting properties of three plant extracts. Food Chem. 141:1902-1907.

Mohanty, A. K., K. Mukhopadhyay, J. K. Kaushik, S. Grover, and V. K. Batish. 2003. Isolation, purification and characterization of chymosin from riverine buffalo (Bubalos bubalis). J. Dairy Res. $70: 37-43$
Nafi', A., H. L. Foo, B. Jamilah, and H. M. Ghazali. 2013. Properties of proteolytic enzyme from ginger (Zingiber officinale Roscoe). Int. Food Res. J. 20:363-368.

Nafi', A., F. H. Ling, J. Bakar, and H. M. Ghazali. 2014. Partial characterization of an enzymatic extract from Bentong ginger (Zingiber officinale var. Bentong). Molecules 19:12336-12348.

Parisi, M., S. Moren, and G. Fernandez. 2002. Characterization of a novel cysteine peptidase from tissue culture of garlic (Allium sativum L.). In Vitro Cell. Dev. Pl. 38:608-612.

Shah, M. A., S. A. Mir, and M. A. Paray. 2014. Plant proteases as milk-clotting enzymes in cheesemaking: A review. Dairy Sci. Technol. 94:5-16.

Shammet, K. M., R. J. Brown, and D. J. McMahon. 1992. Proteolytic activity of some milk-clotting enzymes on $\kappa$-casein. J. Dairy Sci. 75:1373-1379.

Sharma, A., M. Kumari, and M. Jagannadham. 2012. Religiosin C, a cucumisin-like serine protease from Ficus religiosa. Process Biochem. 47:914-921.

Shen, D.-Y., J.-C. Wei, J.-B. Wan, X.-J. Huang, C. Xiang, B.-C. Li, Q.-W. Zhang, Y.-T. Wang, and P. Li. 2014. Four new C-21 steroidal glycosides from Cynanchum otophyllum Schneid. Phytochem. Lett. 9:86-91.

Tao, L., K. Su, Q. Yin, and A. Huang. 2015. New process of buffalo milk cake by the Dregea Sinensis coagulant. Zhongguo Rupin Gongye 43:22-26.

Vairo-Cavalli, S., S. Claver, N. Priolo, and C. Natalucci. 2005. Extraction and partial characterization of a coagulant preparation from Silybum marianum flowers. Its action on bovine caseinate. J. Dairy Res. 72:271-275.

Vreeman, H. J., S. Visser, C. J. Slangen, and J. Van Riel. 1986. Characterization of bovine $\mathrm{k}$-casein fractions and the kinetics of chymosin-induced macropeptide release from carbohydrate-free and carbohydrate-containing fractions determined by high-performance gel-permeation chromatography. Biochem. J. 240:87-97.

Xiao, R., K. Xu, Y. Hou, D. Han, and H. Li. 2007. Preservation methods of Rubing (milk cake). Zhongguo Rupin Gongye 35:17-20.

Zhang, Y., H. Wang, L. Tao, and A.-X. Huang. 2015. Milk-clotting mechanism of Dregea sinensis Hemsl. protease. J. Dairy Sci. 98:8445-8453.

Zhao, Z. M., Z. Sun, M. Chen, Q. Liao, M. Tan, X. Zhang, and S. Yin. 2013. Neuroprotective polyhydroxypregnane glycosides from Cynanchum otophyllum. Steroids 78:1015-1020. 